\title{
Historical and recent aufeis in the Indigirka River basin (Russia)
}

\author{
Olga Makarieva $^{1,2}$, Andrey Shikhov ${ }^{3}$, Nataliia Nesterova ${ }^{2,4}$, and Andrey Ostashov ${ }^{2}$ \\ ${ }^{1}$ Melnikov Permafrost Institute of RAS, Yakutsk, Russia \\ ${ }^{2}$ St. Petersburg State University, St. Petersburg, Russia \\ ${ }^{3}$ Perm State University, Perm, Russia \\ ${ }^{4}$ State Hydrological Institute, St. Petersburg, Russia \\ Correspondence: Olga Makarieva (omakarieva@gmail.com) \\ Received: 16 August 2018 - Discussion started: 31 August 2018 \\ Revised: 7 February 2019 - Accepted: 15 February 2019 - Published: 21 March 2019
}

\begin{abstract}
A detailed spatial geodatabase of aufeis (or naled in Russian) within the Indigirka River watershed (305 $000 \mathrm{~km}^{2}$ ), Russia, was compiled from historical Russian publications (year 1958), topographic maps (years 1970-1980s) and Landsat images (year 2013-2017). Identification of aufeis by late spring Landsat images was performed with a semi-automated approach according to Normalized Difference Snow Index (NDSI) and additional data. After this, a cross-reference index was set for each aufeis field to link and compare historical and satellite-based aufeis datasets.

The aufeis coverage varies from $0.26 \%$ to $1.15 \%$ in different sub-basins within the Indigirka River watershed. The digitized historical archive (Cadastre, 1958) contains the coordinates and characteristics of 896 aufeis fields with a total area of $2064 \mathrm{~km}^{2}$. The Landsat-based dataset included 1213 aufeis fields with a total area of $1287 \mathrm{~km}^{2}$. Accordingly, the satellite-derived total aufeis area is 1.6 times less than the Cadastre (1958) dataset. However, more than 600 aufeis fields identified from Landsat images are missing in the Cadastre (1958) archive. It is therefore possible that the conditions for aufeis formation may have changed from the mid-20th century to the present.

Most present and historical aufeis fields are located in the elevation band of 1000-1200 m. About $60 \%$ of the total aufeis area is represented by just $10 \%$ of the largest aufeis fields. Interannual variability of aufeis area for the period of 2001-2016 was assessed for the Bolshaya Momskaya aufeis and for a group of large aufeis fields (11 aufeis fields with areas from 5 to $70 \mathrm{~km}^{2}$ ) in the basin of the Syuryuktyakh River. The results of this analysis indicate a tendency towards an area decrease in the Bolshaya Momskaya aufeis in recent years, while no reduction in Syuryuktyakh River aufeis area was observed.

The combined digital database of the aufeis is available at https://doi.org/10.1594/PANGAEA.891036.
\end{abstract}

\section{Introduction}

Aufeis (naled in Russian, "icing" in English) is the accumulation of ice that is formed by freezing underground and surface waters on the surface of the earth or ice along streams and river valleys in arctic and subarctic regions. It affects water exchange and economic activity (Alekseev, 1987). Aufeis fields are found in permafrost regions such as Alaska (Slaughter, 1982), Siberia (Alekseev, 1987), Canada (Pollard, 2005), Greenland (Yde and Knudsen, 2005) and others (Yoshikawa et al., 2007). Aufeis formation can result in significant economic expenses as aufeis may negatively affect infrastructure and therefore natural resource extraction (Aufeis of Siberia, Nauka, 1981). Moreover, the springs that often feed aufeis may in some cases be the only source of water for remote communities (Simakov, Shilnikovskaya, 1958a). In Russia, aufeis fields are found in North-east Russia, the Transbaikal region, Yakutia and Western Siberia. Sokolov (1975) estimated the total aufeis water storage in 
Russia to be at least $50 \mathrm{~km}^{3}$, which approximately equals the Indigirka River total annual streamflow.

The main hydrological role of aufeis is the seasonal redistribution of the groundwater component of river run-off, whereby the winter groundwater discharge is released to summer streamflow through the melting of aufeis (Surface water resources, 1972). In most cases, the share of the aufeis component in a river's annual streamflow accounts for $3 \%-$ $7 \%$, reaching $25 \%-30 \%$ in particular river basins with an extremely large proportion of aufeis (Reedyk et al., 1995; Kane and Slaughter, 1973; Sokolov, 1975). The most significant water inflow from aufeis melt takes place in May-June (Sokolov, 1975). For example, the share of the aufeis flow accounts for more than $11 \%$ of total annual streamflow of the Indigirka River (gauging station Yurty, $51100 \mathrm{~km}^{2}$ ). In May, aufeis melt may represent $50 \%$ of monthly total streamflow but decreases in June to $35 \%$ (Sokolov, 1975).

It is important to understand how climate change may impact aufeis formation because warming has been observed in this region, causing the transformation of permafrost (Romanovsky et al., 2007), glaciers' reduction (Ananicheva, 2014) and hydrological regime changes (Bring et al., 2016; Makarieva et al., 2018a). Aufeis is formed by a complex connection between rivers and groundwater. Many studies have reported the increase of minimum flow in Arctic rivers (Rennermalm et al., 2010; Tananaev et al., 2016), including those where aufeis is observed in abundance (Makarieva et al., 2018a). A widely accepted hypothesis for permafrost regions is that a warming climate increases the connection between surface water and groundwater that in turn leads to the increase of streamflow, both in cold seasons and in annual flow (Bense et al., 2012; Ge et al., 2011; Walvoord et al., 2012; Walvoord and Kurylyk, 2016). Variation and changes in aufeis extent can be assessed using remote sensing techniques, whereby aufeis dynamics can serve as an indicator of groundwater change that is otherwise difficult to observe (Topchiev, 2008; Yoshikawa et al., 2007).

The understanding of how aufeis responds to a warming climate varies. Alekseev (2016) suggests 3- to 11-year up and down cycles of aufeis maximum annual size, which may vary up to $25 \%-30 \%$ in comparison with long-term average values. However, the same author (Alekseev, 2016) states a general tendency of a decrease of aufeis volume for the last 50-60 years in some aufeis-affected areas of Russia, such as the Baikal region, South Yakutia, the Kolyma region and the eastern Sayan Mountains, following the increase of global and local air temperature.

Some authors suggest that degradation of permafrost in the discontinuous and sporadic permafrost regions will lead to the decrease of the number of aufeis fields and even an almost complete disappearance. Meanwhile, in the zone of continuous permafrost in North-east Siberia, a climate warming of $2-3^{\circ} \mathrm{N}$ is not projected to lead to significant changes in permafrost extent but will increase the number and size of both through and open taliks by the end of the 21th century
(Pomortsev et al., 2010). Such a scenario may result in the reduction of area of large aufeis fields and formation of new small aufeis fields (Pomortsev et al., 2010).

In Alaska as well, no significant changes were documented in the area and volume of aufeis over the past few decades or even a century (Yoshikawa et al., 2007). Yoshikawa et al. (2007) suggested that the formation and the melting of ice are less dependent on climate and more so on the source (spring) water properties such as temperature and volume.

In 1958, Simakov and Shilnikovskaya (1958a) compiled and published a map inventory of aufeis of the North-east USSR (scale $1: 2000000$ ). Since then, there has been no update on the information on aufeis in this region, apart from some specific studies. In 1980-1982, an inventory of aufeis in the zone of the Baikal-Amur Mainline was published (Catalog of Aufeis in the Baikal-Amur Railroad Zone, 1980, 1981, 1982). Markov et al. (2016) summarized the results of field studies on aufeis in the southern mountain taiga of Eastern Siberia from 1976 to 1983. Grosse and Jones (2011) compiled a spatial geodatabase of frost mounds (or pingos) for northern Asia from topographic maps. Further, the glacier science community has mapped past and recent glacier cover across the globe (GLIMS and NSIDC, 2005, updated 2017). However, as far as the authors are aware, no electronic catalogue of aufeis exists.

The aim of this study is to update the inventory of aufeis in North-east Russia using Landsat images, as well as to develop an electronic catalogue, which will contain data on historic and current locations and characteristics of aufeis. Here we present work that has been completed for the Indigirka River basin (down to the Vorontsovo gauging station, $305000 \mathrm{~km}^{2}$ ).

The new database, which includes geographic information system (GIS) formatted files, is freely available (Makarieva et al., 2018b) and can be used both for scientific purposes and for solving practical problems such as engineering construction and water supply.

\section{Study region}

The study region is the Indigirka River basin, which is located in North-east Siberia and covers an area of $305000 \mathrm{~km}^{2}$ (Fig. 1). Most of the basin is represented by highlands with a number of mountain ranges $(<3003 \mathrm{~m})$ including the Cherskiy and Suntar-Khayata mountains. The lowland elevation reaches heights up to $350 \mathrm{~m}$.

The climate of the study area is distinctly continental with annual average and lowest monthly air temperature varying from -16.1 and $-47.1^{\circ} \mathrm{N}$, respectively, at the Oymyakon meteorological station $(726 \mathrm{~m} ; 1930-2012)$ to -13.1 and $-33.8^{\circ} \mathrm{N}$, respectively, at the Vostochnaya station (1288 m; 1942-2012). Most precipitation (over 60\%) occurs in the summer season. Average annual precipitation 


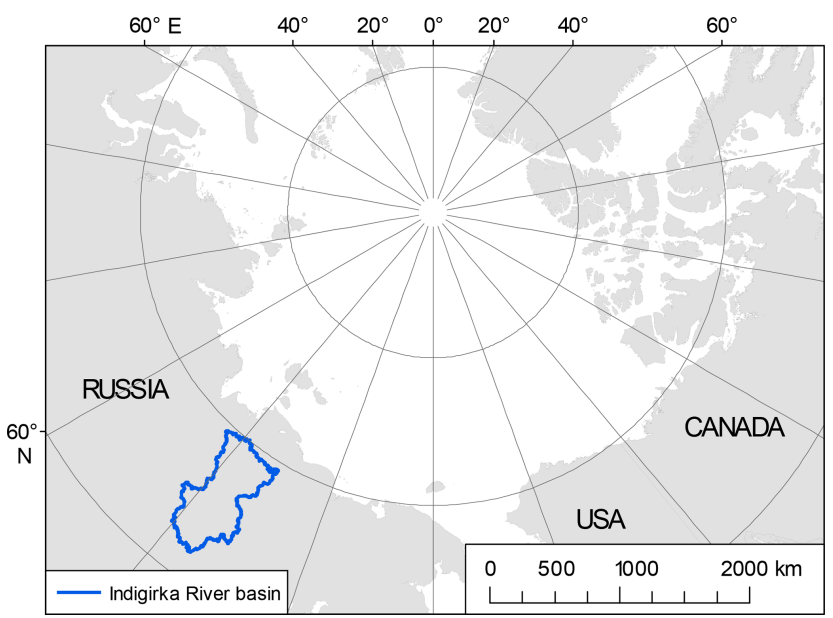

Figure 1. Geographical location of the Indigirka River basin.

at the Oymyakon weather station is $180 \mathrm{~mm}$ and at the Vostochnaya station $278 \mathrm{~mm}$.

The Indigirka River basin is located in the zone of continuous permafrost. Permafrost depth can reach $450 \mathrm{~m}$ in the mountains, up to $180 \mathrm{~m}$ in river valleys and intermountain areas, with taliks found in riverbeds and fractured fields. The hydrogeological regime is affected by the active layer, which varies from $0.3 \mathrm{~m}$ to over $2 \mathrm{~m}$ (Explanatory note to the geocryological map of the USSR, 1991). The river run-off regime is characterized by high snowmelt freshet, summerautumn rainfall floods and low winter flow. In winter, smalland medium-sized rivers completely freeze. Freshet starts in May-June and lasts for approximately 1.5 months. Meltwater from aufeis, glaciers and snow patches adds to the river discharge in summer.

In total, about 10000 aufeis fields with a total combined area of about $14000 \mathrm{~km}^{2}$ (Sokolov, 1975) are known in North-east Russia. The watershed area covered by aufeis varies from $0.4 \%$ to $1.3 \%$, reaching $4 \%$ in some river basins (Tolstikhin, 1974). Most aufeis is of ground water origin; significantly less often it is formed from river water or is of a mixed type (Tolstikhin, 1974).

\section{Materials and methods}

\subsection{The database of aufeis based on the Cadastre (1958) and topographic maps}

The inventory map (scale 1:2000000) and the Cadastre of aufeis of the North-east USSR (Simakov and Shilnikovskaya, 1958b), hereinafter referred to as the Cadastral map and the Cadastre, became the first summarizing quantitative work on aufeis within the territory. The effort was carried out in the framework of the Central complex thematic expedition of the North-East Geological Survey of the USSR.

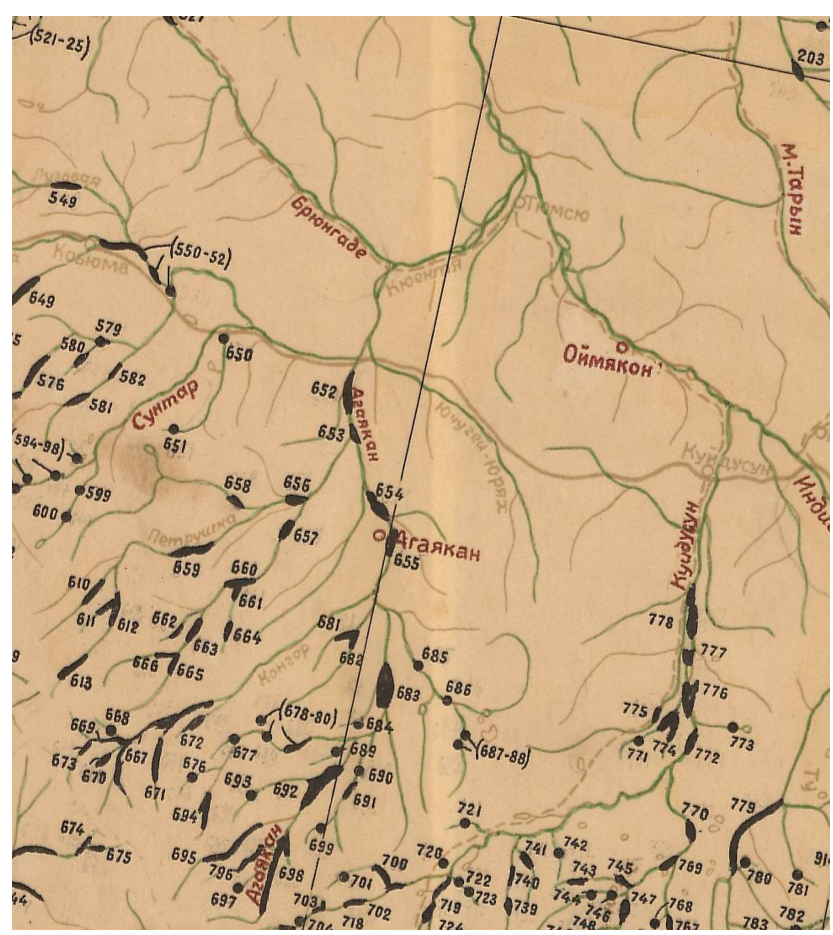

Figure 2. A section of the Cadastral map of the North-east USSR from 1958 (sheet 7, upper reaches of the Indigirka River - the basins of the rivers Suntar, Agayakan and Kuydusun).

The Cadastre contains data on 7448 aufeis fields of different size and over 2000 boolgunyakhs (frost mounds). Of the total number of aufeis fields, 7006 are plotted based on air-photo interpretation data and another 442 based on geological reports from field data. It should be noted that aufeis was identified based on geomorphologic features, meaning that in some cases only the areas or river valleys with aufeis were identified but not aufeis itself.

In the Cadastre (1958) and our digitalization, the following characteristics of the aufeis are presented: location (the name of the river, the distance from the mouth or source), size (maximum length, average width and area) and the dates of ice recording in aerial images (ranging from 8 June 1944 to 27 September 1945). Areas of the aufeis were evaluated via planimetry.

Only very large aufeis fields $\left(>3.3 \mathrm{~km}^{2}\right)$ were plotted on the Cadastral map (1958), while others are shown as point locations. Each aufeis field on the Cadastral map (1958) has its corresponding number, whose identifier and corresponding information can be found in the Cadastre (1958). As noted by Simakov and Shilnikovskaya (1958a), some very small aufeis fields $\left(<0.01 \mathrm{~km}^{2}\right)$ could have been missed due to their indecipherability on aerial images, or they might have already melted at the time of the aerial photograph. The example of the Cadastral map's sheet (1958) for the Indigirka River upper reaches is presented in Fig. 2. 
Here, we developed the GIS database of aufeis in the Indigirka River basin up to the cross section at the Vorontsovo gauging station based on the Cadastre (1958) and topographic maps. Our compilation contains data on 896 aufeis fields. The aufeis fields are presented as point objects in our database. The areas are specified for only 808 aufeis fields. The total area of all the aufeis fields within the specified area accounts for $2063.6 \mathrm{~km}^{2}$ and the areas of individual aufeis fields vary from 0.01 to $82 \mathrm{~km}^{2}$.

In the Cadastre, the dates of ice recording for 592 aufeis fields $(66 \%)$ are presented, based on aerial images within the study area. The average seasonal date of recording is $2 \mathrm{Au}-$ gust, ranging from 8 June to 27 September. The dates of ice recording for the remaining $34 \%$ of the aufeis were not described, meaning that aufeis detection could be carried out based not on the visible ice presence at the aerial images but on geomorphological features of river valleys. Therefore, the Cadastre might contain data on old aufeis glades, where the aufeis itself was absent.

Spatial positioning of the Cadastral map of aufeis was conducted using the location description by Russian topographic maps with the scale of $1: 200000$. Grosse and Jones (2011) used the same set of maps for compiling the dataset of pingos (frost mounds) in northern Asia and described those maps in details therein. The maps at 1:200000 scale were based on more detailed maps of $1: 50000$ and $1: 100000$ scale, which were derived from aerial photography acquired in the 19701980s. The use of the 1:200000 scale guarantees the position assessment precision to within $100 \mathrm{~m}$. Each map sheet was visually searched for aufeis, and identified aufeis was marked with an area polygon in a GIS layer. The locations of 330 aufeis fields (area $358 \mathrm{~km}^{2}$ ) were determined based on topographic maps. When digitized, a point was plotted in the middle of aufeis on a topographic map.

The locations of the remaining aufeis were determined with the spatially positioned map of the Cadastre. Additionally, 11 aufeis fields were found which were absent in the Cadastre but present in the topographic maps. Aufeis areas were estimated using digitalization of the maps. Areas of the remaining aufeis were estimated with the Cadastre. It was not possible to estimate the area of 88 aufeis fields, as they were not drawn on the topographic maps, and only their location, but not area, was stated in the Cadastre.

\subsection{Identification of aufeis based on Landsat data}

Aufeis location and area are relatively easy to determine using Landsat and/or Sentinel-2 images, received immediately after snow cover melt. Snow and ice are known to be characterized by relatively high reflectance in the visible and nearinfrared spectral bands and its significant decrease in the mid-infrared band. The Normalized Difference Snow Index (NDSI) is based on this pattern and is calculated according to the formula (Hall et al., 1995):

NDSI $=($ GREEN - SWIR 1$) /($ GREEN + SWIR 1$)$,

where SWIR1 is reflectance in the mid-infrared band (1.56$1.66 \mu \mathrm{m}$ for the Landsat-8 images), and GREEN is reflectance in the green band $(0.525-0.6 \mu \mathrm{m}$ for the Landsat8 images). Following Hall et al. (1995), the threshold value for snow and ice is set at 0.4. Apart from using NDSI, other indices have been suggested to detect aufeis using Landsat images (but not used here). These are the Normalized Difference Glacier Index (NDGI) and the Maximum Difference Ice Index (MDII). Their advantages and disadvantages are discussed by Morse and Wolfe (2015).

Landsat-based detection of aufeis required some additional data to exclude other surface types with similar spectral characteristics, such as snow-covered areas and turbid water. It is problematic to separate floodplain lakes from aufeis using late spring satellite images because many of these lakes are still ice-covered in May-June. Morse and Wolfe (2015) recommended creating a mask of water surface using midsummer images (when all water bodies are not already covered by ice), to exclude them from further analysis.

Aufeis detection in the Indigirka River basin was carried out based on the Landsat-8 OLI satellite images, from 2013 to 2017 , downloaded from the United States Geological Survey web-service (https://earthexplorer.usgs.gov, last access: 26 February 2019). We used Landsat 8 Collection 1 Level 1 terrain-corrected product (L1T) with radiometric and geometric corrections. In total, 33 images completely covering the Indigirka River basin were processed. We selected late spring images (between 15 May and 18 June) to detect the maximum possible number of aufeis fields, since in June they melt intensively. There was between $1 \%$ and $20 \%$ of cloudiness in some images.

Preprocessing of the images was performed with the use of the Semi-Automatic Classification Plugin module (QGIS 2.18). It includes the calculation of surface reflectance and atmospheric correction using the Dark Object Subtraction (DOS1) image-based algorithm described by Chavez (1996).

The Aufeis detection algorithm was realized in ArcGIS with the help of the ModelBuilder application. Apart from the Landsat images, the digital terrain model GMTED2010 (Danielson and Gesch, 2011) with a spatial resolution of $250 \mathrm{~m}$ was used to build a network of thalwegs within the study basin. This is essential for semi-automated separation of the aufeis from snow-covered areas in late spring Landsat images. Indeed, almost all aufeis is located either at streams or thalwegs, or in immediate proximity to them. On the contrary, snow cover in late spring mainly remains on mountain ridges and other elevated locations, i.e. relatively far from thalwegs. Based on the preliminary analysis of aufeis location in relation to the network of thalwegs created, we found that a $1.5 \mathrm{~km}$ wide buffer zone around the thalwegs covers almost all aufeis. So, snow- and ice-covered areas, which are 
located outside this buffer, are excluded from further analysis.

The process of aufeis detection using Landsat images consisted of the following steps:

- detection of snow-ice bodies with a NDSI threshold of 0.4 ;

- creation of a water mask with threshold values of the Normalized Difference Water Index (NDWI; taken equal to 0.3 ) and reflectance in the near-infrared band (taken equal to 0.04 );

- extraction of the detected snow-ice bodies by the buffer zone around thalwegs ( $1.5 \mathrm{~km}$ wide);

- conversion to vector format, area calculation and removal of objects smaller than five Landsat pixels (0.45 ha).

The suggested algorithm allows successful aufeis detection if an image is predominantly snow-free. At the end of May and early June, many aufeis fields in mountain regions are still covered by snow. Their detection required later images, obtained in mid-June.

Morse and Wolfe (2015) suggested a new spectral index, MDII, for automatically distinguishing snow bodies from ice ones. However, here some of the high-elevation aufeis fields were partially covered with snow at the image acquisition time. Instead of automatic processing, the outlining of high elevation aufeis was conducted manually when snow cover was present, with separation of aufeis from adjacent snowcovered areas.

Further, during melt season, the aufeis often divides into several neighbouring areas. When assessing the number of aufeis fields with satellite data, it is therefore necessary to aggregate the areas into one aufeis field if they are located at a distance $<150 \mathrm{~m}$ (or five Landsat pixels) from each other and within one aufeis glade.

As a result of semi-automated processing of Landsat images, aufeis with a total area of $1253.9 \mathrm{~km}^{2}$ was detected. During the subsequent comparison with the Cadastre data (see Sect. 3.3 for more details), over 100 aufeis fields, with a total area of $33.5 \mathrm{~km}^{2}$, were delineated manually. The gaps were mainly due to the presence of snow cover and/or cloud coverage in the images. To reduce the number of gaps, two to three images from the same area were used. The total number of aufeis fields, identified with the Landsat images in the Indigirka River basin, was 1213, and their total area was $1287.4 \mathrm{~km}^{2}$. Therefore, an omission error of automatic aufeis detection can be estimated as $2.7 \%$ of their total area.

The structure of the GIS dataset of aufeis according to Landsat images is presented in Table 2.

\subsection{Cross reference between historical and satellite-based aufeis data collection}

Cross-verification of aufeis data collection using the Cadastre (1958) and satellite imagery was performed in two steps. In the first step, we found the closest aufeis field in the Landsat-derived dataset for each aufeis field from the Cadastre data if the distance between them was less than $5000 \mathrm{~m}$. The determination of search radius was based on a preliminary analysis of the aufeis locations by the Cadastre in relation to the Landsat-based dataset. As a result, the cross index (identifier of the closest aufeis in the Landsat-derived dataset) and minimum distance ( $\mathrm{m}$ ) to the closest aufeis were determined for aufeis from the Cadastre. For the Landsatbased dataset, the cross index is the key field for the reference to the dataset from the Cadastre.

In the second step, a full manual verification was performed to find the mistakenly interrelated aufeis. For example, if the closest aufeis fields from the Cadastre and from the Landsat-based dataset were at a distance of less than $5000 \mathrm{~m}$ but in different thalwegs, they were considered to be different (unrelated) aufeis fields.

In total, 260 aufeis fields from the Cadastre were not verified by Landsat images. For them, the NoData value (-9999) was set in the CrossIndex and Distance_m fields of the attributive table (see Table 1 for the structure of the GIS dataset from Cadastre).

\section{Results}

\subsection{Comparison of the historical and modern data collection}

The results of the comparison are presented in Table 3. In total, 634 aufeis fields from the Cadastre were found by the Landsat images. They correspond to 611 aufeis fields identified with the images, meaning that in 23 cases, one aufeis field in an image corresponds to two aufeis fields in the Cadastre. But 262 aufeis fields from the Cadastre were not detected by the satellite images. Those are mainly small aufeis fields, which melt by the middle of June. However, among them there are also 43 large aufeis fields over $1 \mathrm{~km}^{2}$ (Fig. 3a). It is likely that since the mid-20th century, when the field observations were conducted and the Cadastre of aufeis was compiled, some aufeis could have disappeared.

A little over half of the aufeis detected by Landsat images is included in the Cadastre: a total of 602 aufeis fields detected (the total area of $250.4 \mathrm{~km}^{2}$ ) are not included in the Cadastre (Fig. 3b). Such a significant difference can be caused for the following reasons:

1. In some cases a single aufeis field, according to the Cadastre, corresponds to two or more aufeis fields in a satellite image. 
Table 1. The structure of the GIS database of aufeis using Cadastre (1958).

\begin{tabular}{|c|c|c|}
\hline Field name & Field alias & Description \\
\hline FID & FID & Index number (Object ID) \\
\hline AufDataSrc & Aufeis data source & Aufeis Cadastre data (1958) (for all objects) \\
\hline Auf_area & Aufeis area Cadastre $\left(\mathrm{km}^{2}\right)$ & $\begin{array}{l}\text { Aufeis area }\left(\mathrm{km}^{2}\right) \text { from the Cadastre (1958). If the data were missing, the area } \\
\text { was calculated using topographic maps (1980) of scale } 1: 200000 .\end{array}$ \\
\hline Auf_index & Aufeis index Cadastre & $\begin{array}{l}\text { Index of the aufeis in the Cadastre (1958) (it contains } 0 \text { if the aufeis was } \\
\text { missing in the Cadastre but found in the topographic map (1980) of scale } \\
1: 200000)\end{array}$ \\
\hline Map_index & Cadastre map index & of the Cadastre (1958) map \\
\hline Auf_topo & Aufeis in topo & Presence of aufeis in topographic map ( 0 - missing, 1 - present $)$ \\
\hline Auf_in_map & Aufeis in map & Presence of aufeis in the Cadastre $(0-$ missing, 1 - present $)$ \\
\hline Toponumber & Topo number & Nomenclature of the topographic map sheet \\
\hline Date & Date & Date of fixing the presence of ice within the aufeis \\
\hline Long. & Long. & Longitude, degree \\
\hline Lat. & Lat. & Latitude, degree \\
\hline Elevation & Elevation & Height above sea level (determined by Aster GDEM; m) \\
\hline Comment & Comment & $\begin{array}{l}\text { Comments (mainly typos in the Cadastre map or the method of } \\
\text { determining aufeis area) }\end{array}$ \\
\hline CrossIndex & Cross index & $\begin{array}{l}\text { Cross index of aufeis derived from Landsat (if aufeis is not in Landsat, the } \\
\text { value is missing) }\end{array}$ \\
\hline Distance_m & Distance (m) & $\begin{array}{l}\text { Minimum distance between the aufeis from the Cadastre and the same aufeis } \\
\text { from Landsat image }(\mathrm{m})\end{array}$ \\
\hline
\end{tabular}

Table 2. The structure of the GIS database of aufeis using Landsat images (2013-2017).

\begin{tabular}{|c|c|c|}
\hline Field name & Field alias & Description \\
\hline FID & FID & Index number (Object ID) \\
\hline AufDataSrc & Aufeis data source & Landsat images (for all objects) \\
\hline WRS2_ID & Landsat WRS2_ID & $\begin{array}{l}\text { The Landsat scene identifier in the WRS } 2 \text { graph of the US Geological Survey } \\
\text { (USGS). The first three digits indicate the column number, and the last three digits } \\
\text { represent the line number. }\end{array}$ \\
\hline Image_Date & Landsat image date & The date of the image \\
\hline Comment & Comment & $\begin{array}{l}\text { Additional information, for example, if the aufeis was partly covered by clouds and } \\
\text { additional images were used to estimate the area }\end{array}$ \\
\hline CrossIndex & Cross index & $\begin{array}{l}\text { Identifier of aufeis using Landsat images (key field for the reference to } \\
\text { the Cadastre data) }\end{array}$ \\
\hline Auf_Area & Aufeis area $\left(\mathrm{km}^{2}\right)$ & Aufeis area by Landsat image $\left(\mathrm{km}^{2}\right)$ \\
\hline Elevation & Average elevation & Average elevation of aufeis, calculated by Aster GDEM digital elevation model \\
\hline
\end{tabular}

2. Aufeis is characterized by significant interannual variability, which results in possible formation of new aufeis in areas where it was previously not observed (Alekseev, 2015; Pomortsev et al., 2010; Atlas of snow and ice resources of the world, 1997).

Total aufeis area evaluated based on satellite images appeared to be 1.6 times smaller than stated in the Cadastre (1958). First and foremost, such a difference can be explained by the fact that it was not the area of the aufeis itself but instead the aufeis glades that were reported in the Cadastre (1958), and this corresponds to the maximum aufeis area during one or several seasons. With the satellite data, the ar- eas of the aufeis itself were assessed, and when mid-June images were used, the aufeis area was significantly smaller than the typical annual maximum.

Aufeis area distribution according to the Cadastre and satellite data is shown as Lorenz curves (Fig. 4). In both cases, the shape of the curves signifies a high degree of irregularity which is similar: $10 \%$ of the largest aufeis fields make up $61 \%$ and $57 \%$ of their total area according to the Landsat and the Cadastre data, respectively.

The cross-verification of the Cadastre and satellite data shows that almost $60 \%$ of aufeis fields that are unconfirmed in the Landsat imagery and that are therefore only present 
Table 3. Data correlation of aufeis based on the Cadastre (1958) and the Landsat images.

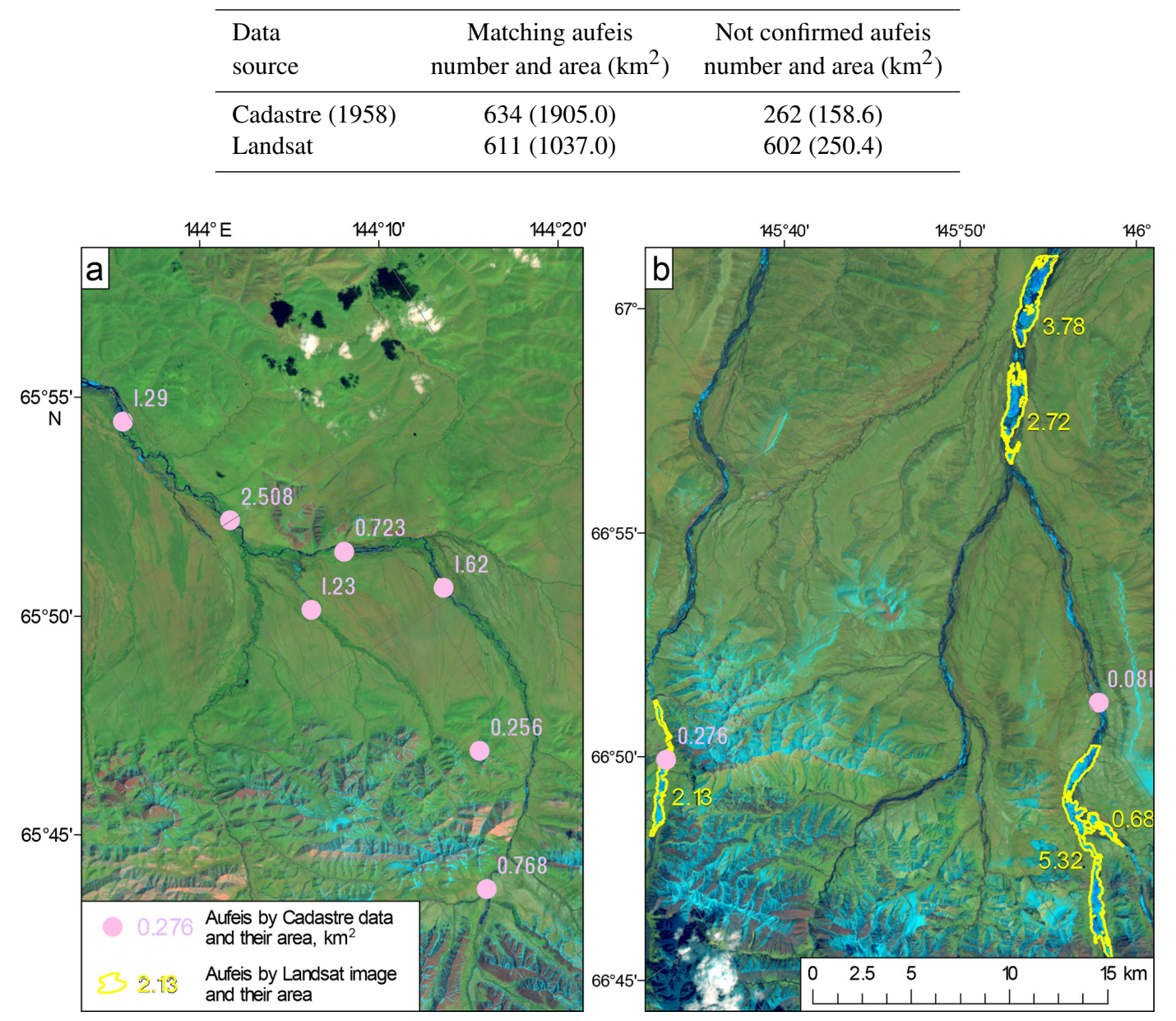

Figure 3. Difference between aufeis location according to the Cadastre and satellite data: (a) aufeis fields are absent in the image but present in the Cadastre (Landsat-8 image of 18 June 2017) and (b) aufeis fields are absent (or their area is understated) in the Cadastre but present in the image (Landsat-8 image of 30 May 2016).

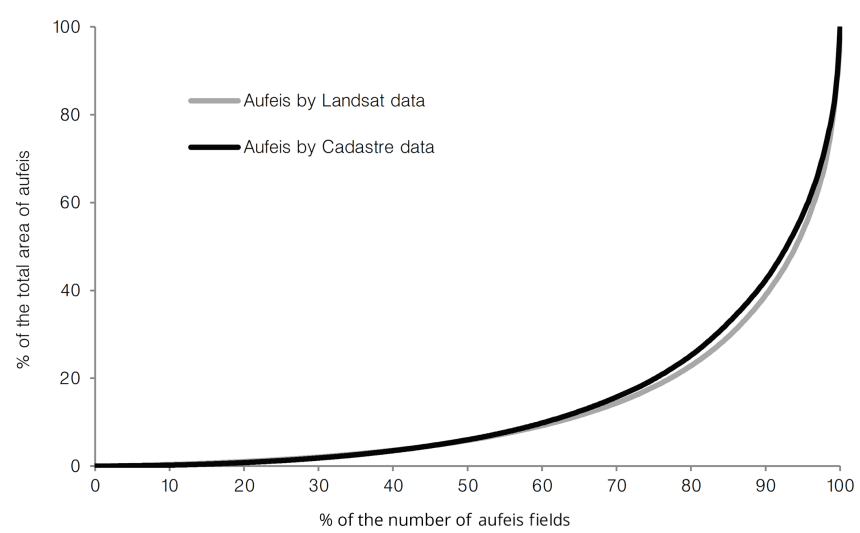

Figure 4. Lorenz curves illustrating aufeis area distribution according to the Cadastre and Landsat data. in the Cadastre have an individual aufeis area of less than $0.25 \mathrm{~km}^{2}$ (Fig. 5a). The confirmed aufeis accounts for about $20 \%$ of the area stated in the Cadastre. Thus, it was mainly small aufeis fields that were not confirmed in the Landsat images. Conversely, Fig. $5 \mathrm{~b}$ shows that almost $60 \%$ of the aufeis fields detected in the Landsat images but not listed in the Cadastre have an area of less than $0.25 \mathrm{~km}^{2}$ each.

\subsection{Aufeis distribution by elevation}

In general, aufeis distributions by elevation as assessed using the Cadastre and Landsat data are quite similar, although there are some differences that are elevation-specific (Fig. 6). Most aufeis is located in the elevation band of $1000-1200 \mathrm{~m}$. At lower elevations (up to $800 \mathrm{~m}$ ) the number of aufeis fields according to Landsat data is higher than stated in the Cadastre. At the elevations of 1400-2000 m, more aufeis is identified in the Cadastre data than in the satellite images. This 

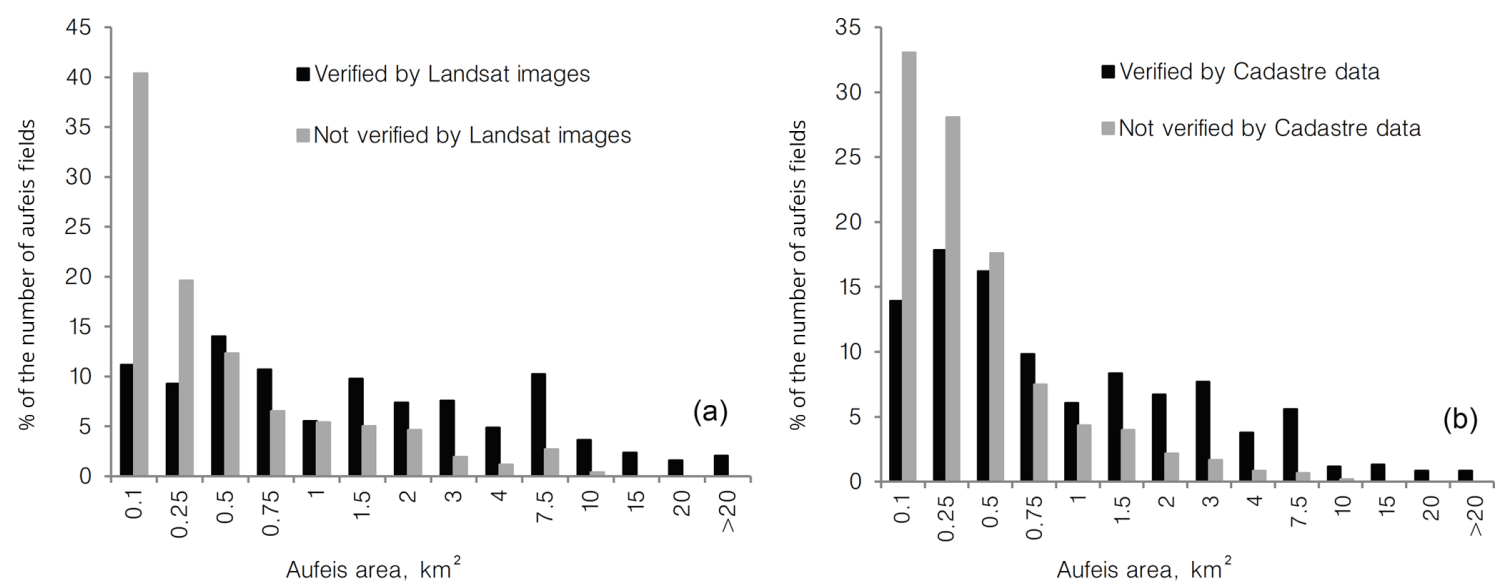

Figure 5. Aufeis area distribution: (a) according to the Cadastre data, confirmed and not confirmed by Landsat images and (b) according to Landsat images, confirmed and not confirmed by the Cadastre.

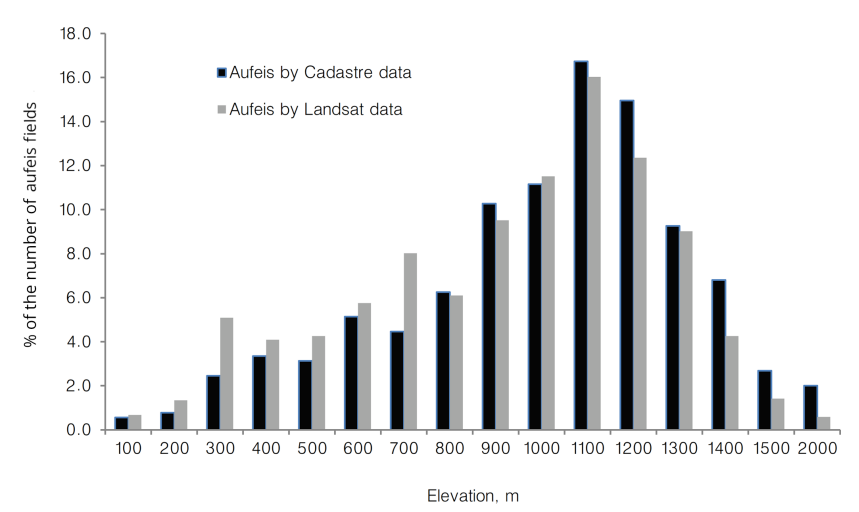

Figure 6. Aufeis distribution by elevation within the Indigirka River basin.

can be explained by the fact that many aufeis fields located at high altitudes often have a small area, so they could have been missed during the analysis of the satellite data. Further, they could have been covered with snow at the image acquisition time, which would increase the possibility of them being missed.

The elevation band of $200-300 \mathrm{~m}$ is characterized by the location of large aufeis fields. Though less than $2.5 \%$ and $5.0 \%$ of aufeis fields by the Cadastre and Landsat images are situated here, they represent about $11 \%$ and $13 \%$ of aufeis area from the datasets respectively (Fig. 7).

\subsection{Aufeis distribution by river basins}

In the Indigirka River basin, there are several zones with a high density of aufeis: in the southern part (the Suntar and Kuidusun River basins) as well as in the central part (Chersky Range slopes) (Fig. 8). The largest aufeis fields identified by satellite images are located in the Syuryuktyakh River basin on the north-east slopes of the Chersky Range. Meanwhile,

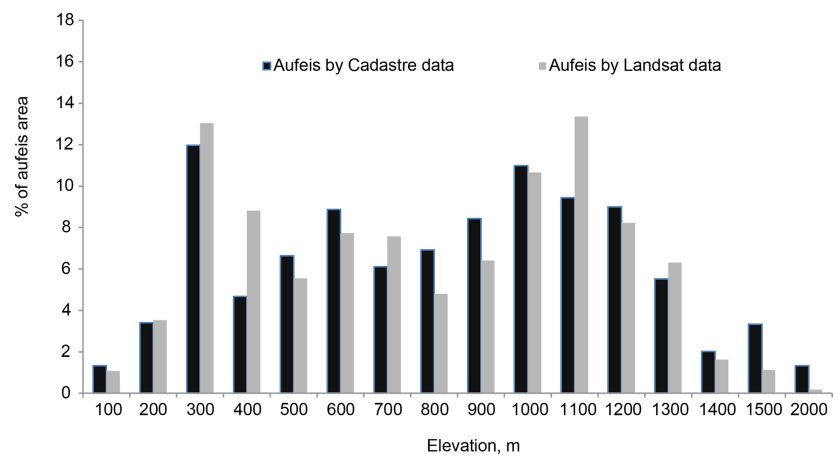

Figure 7. Aufeis area distribution by elevation within the Indigirka River basin.

aufeis is almost absent in the northernmost (lowland) part of the Indigirka basin.

We analysed the aufeis coverage for six river basins with available streamflow data. The headwater part of the Indigirka River, with the gauge near the Yurty village (area $51100 \mathrm{~km}^{2}$ ), is the basin with the largest aufeis coverage (Table 4). Correlation between average elevation of the basins and their aufeis coverage (expressed as a percentage) is statistically significant. Among six basins, the Spearman rank correlation coefficients between the basin average elevation and aufeis percentage are 0.71 and 0.77 by the Cadastre and satellite data, respectively.

\subsection{Aufeis area interannual variability}

The assessment of aufeis area interannual variability was conducted in two areas: for the Bolshaya Momskaya aufeis, which is located in the Moma River channel (area in the Cadastre is $82 \mathrm{~km}^{2}$ ), and for a group of large aufeis (total area in the Cadastre is $287.8 \mathrm{~km}^{2}$ ) in the Syuryuktyakh River basin, which is the left-bank tributary of the Indigirka River. 
Table 4. Aufeis area coverage (percentage) in the sub-basins within the Indigirka River watershed by the Cadastre and Landsat data.

\begin{tabular}{lrrrr}
\hline & $\begin{array}{r}\text { Area, } \\
\mathrm{km}^{2}\end{array}$ & $\begin{array}{r}\text { Average } \\
\text { elevation, } \\
\mathrm{m} \text { a.s.l. }\end{array}$ & $\begin{array}{r}\text { \% aufeis } \\
\text { coverage } \\
\text { (Cadastre) }\end{array}$ & $\begin{array}{r}\% \text { aufeis } \\
\text { coverage } \\
\text { (Landsat) }\end{array}$ \\
\hline River & 7680 & 1460 & 0.97 & 0.78 \\
Suntar River - Sakharinya River mouth & 17600 & 1104 & 0.49 & 0.23 \\
Nera - Ala-Chubuk & 22300 & 1174 & 0.32 & 0.26 \\
Indigirka - Yurty & 51100 & 1256 & 1.15 & 0.80 \\
Indigirka - Indigirskiy & 83500 & 1185 & 0.82 & 0.56 \\
Indigirka - Vorontsovo & 305000 & 803 & 0.68 & 0.41 \\
\hline
\end{tabular}

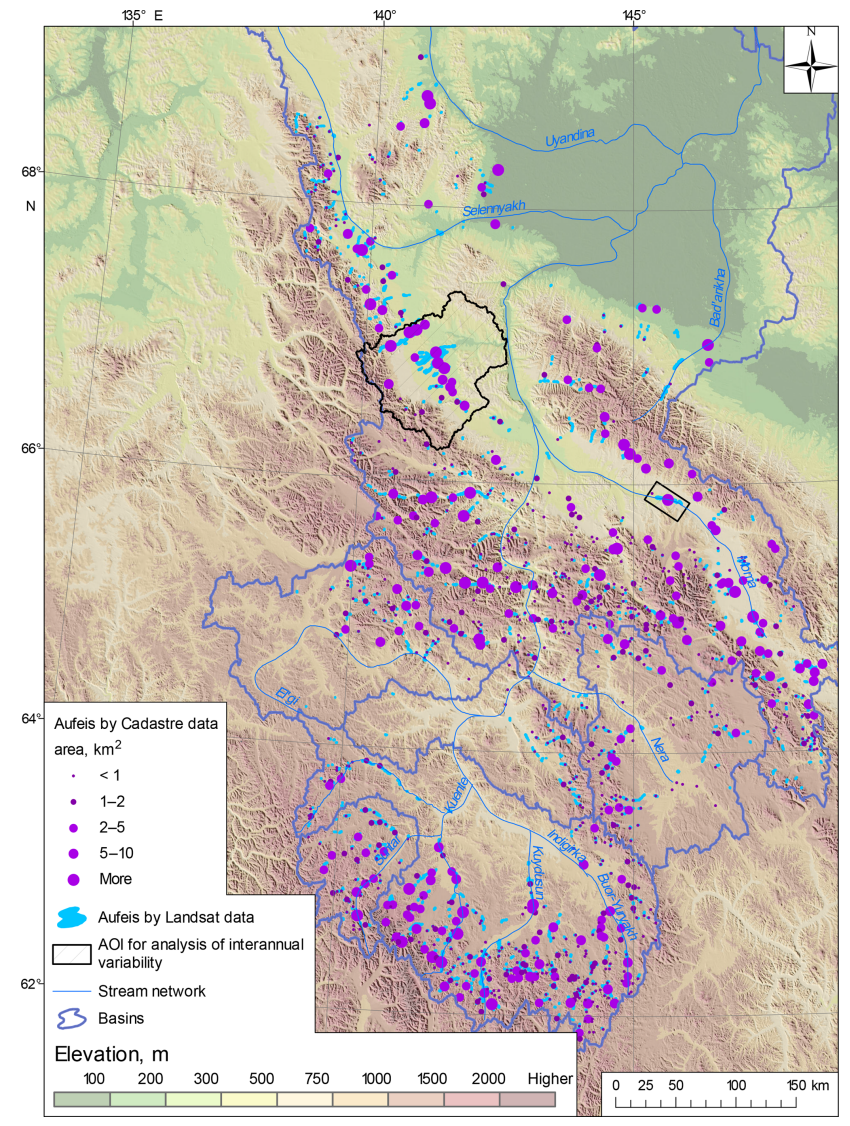

Figure 8. Aufeis in the Indigirka River basin according to the Cadastre and Landsat images. Black outlines represent the zones where aufeis area interannual variability was assessed.

Cloudless images from Landsat-5 (TM), Landsat 7 $($ ETM+) and Landsat-8 (OLI) were used with the acquisition dates between 1 May and 30 June. In the USGS archives, there are no Landsat-5 images for the study area for the 1984-2007 period. This limits the duration of satellite observations on aufeis to the period since 1999 (when the Landsat7 satellite was launched). Also, the clouds complicate the acquisition of representative data. The list of the acquisition dates and assessed aufeis area values is presented in Table 5.
Table 5. Aufeis area changes, 2001-2017.

\begin{tabular}{|c|c|c|c|}
\hline \multicolumn{2}{|c|}{ Bolshaya Momskaya aufeis } & \multicolumn{2}{|c|}{$\begin{array}{l}\text { Group of aufeis fields in } \\
\text { the Syuryuktyakh River basin }\end{array}$} \\
\hline Image date & $\begin{array}{r}\text { Aufeis } \\
\text { area, } \mathrm{km}^{2}\end{array}$ & Image date & $\begin{array}{r}\text { Aufeis } \\
\text { area, } \mathrm{km}^{2}\end{array}$ \\
\hline 17 Jun 2002 & 29.2 & 26 Jun 2001 & 69.7 \\
\hline 8 May 2005 & 66.2 & 29 Jun 2002 & 100.6 \\
\hline 27 May 2006 & 57.9 & 4 Jun 2007 & 155.1 \\
\hline 19 Jun 2009 & 39.5 & 17 Jun 2009 & 117.5 \\
\hline 25 May 2011 & 61.7 & 22 Jun 2011 & 89.5 \\
\hline 27 May 2012 & 49.6 & 21 May 2014 & 268 \\
\hline 15 May 2013 & 48.1 & 18 Jun 2015 & 164.8 \\
\hline 18 Jun 2017 & 21.9 & 04 Jun 2016 & 206.4 \\
\hline
\end{tabular}

Both areas are located at low elevations (Bolshaya Momskaya 430 to $500 \mathrm{~m}$ and Syuryuktyakh 200 to $500 \mathrm{~m}$ ), which contributes to the relatively early and intensive aufeis melt in spring. The aufeis fields reach their maximum area by the beginning of May. Using the available satellite images it is impossible to make a reliable conclusion on aufeis area increase or decline because the acquisition dates vary significantly from year to year. However, it is possible to make some conclusions based on the available data, detailed below.

In 2002-2017 the Bolshaya Momskaya aufeis did not reach the maximum area stated in the Cadastre $\left(82 \mathrm{~km}^{2}\right)$, even though the satellite image was acquired during the first week of May (2005) when aufeis melting had not yet started. Comparing two images, taken in similar conditions (8 May 2005 and 15 May 2013), it was found that aufeis area in 2013 was smaller than in 2005 by $18.1 \mathrm{~km}^{2}$. Accordingly, the Bolshaya Momskaya aufeis may have seen a decreasing trend over time in its maximum coverage.

The area of the largest aufeis field in the Syuryuktyakh River basin in May 2014 was $78.0 \mathrm{~km}^{2}$, which is $8 \mathrm{~km}^{2}$ larger than stated in the Cadastre. One may note also that the maximum aufeis areas in the Syuryuktyakh River basin were detected by the images received at the end of the period (20142017), including mid-June (18 June 2015). Therefore, it can 
be suggested that the aufeis areas within the Syuryuktyakh River basin have not decreased since 2002.

\section{Discussion}

The most important uncertainty in the obtained results relates to our ability to draw a conclusion on the long-term trend of total aufeis area comparing the historical and satellitederived datasets. The total area of aufeis estimated by Landsat images is $38 \%$ less than according to the Cadastre. Is it possible to confirm that such a significant reduction in the aufeis area really occurred? Considering this issue, it is important to emphasize some limitations of the methodology and the datasets created.

The main limitation of the historical aufeis dataset is that the Cadastre provides an area of aufeis glades but not the aufeis itself. Simakov and Shilnikovskaya (1958a) noted that the areas of aufeis glades match the average annual maximum of the ice-covered area. Alekseev (2005) states that the assessment of the stages and patterns of the development of aufeis glades based on the analysis of their landscape and geomorphological features is difficult due to the lack of research on temporal aspects of mutual transitions of landscape facies and their factorial dependencies. However, studying the aufeis landscapes in the central part of the Eastern Sayan Mountains, Alekseev (2005) assumed that the vegetation community which is a typical indicator of aufeis development may persist for 200-300 years after the beginning of aufeis processes attenuation.

The satellite-derived assessment of the aufeis area has the following main source of uncertainty. It is often impossible to determine the maximum area of aufeis by satellite images, since it is observed at the beginning of the snowmelt season, when aufeis is still covered with snow. In late spring and the beginning of summer, the area of aufeis may already have significantly reduced in comparison with the maximum values, due to melting and mechanical destruction.

Maximum intensity of aufeis melt in the studied region is observed in June when spring flood river streams actively erode the aufeis surface. Sokolov (1975) reported the results of the observations at the Anmyngynda aufeis carried out in 1962-1965. This aufeis is located in the upstream area of the Kolyma River basin (723 m a.s.1.) and may be used as being representative of the mountainous part of the studied region. In 1962-1965, the aufeis area changed from 5.1 to $6.2 \mathrm{~km}^{2}$, with a mean maximum area of $5.7 \mathrm{~km}^{2}$. Aufeis melt has been observed to begin on average on the 10 May. During May, the aufeis area decreased by $15 \%$ of the total area on average. At the end of June, the remaining area was $34 \%$ of the maximum; i.e. during this month more than $50 \%$ of the aufeis area was destroyed. In the period from July to September, the melting slowed down: in July the aufeis decreased by $22 \%$, in August by $8 \%$ and in September by $3 \%$. The area of aufeis at lower absolute elevations decreases faster in the first half of the summer and in the upstream areas in the second half (Sokolov, 1975).

Some aufeis in the mountainous regions could be missed by satellite images, since it can be covered with snow until the end of June. However, its contribution to the total area is non-significant.

Taking into account all the above-described limitations, and also that more than 600 aufeis fields that were missing in the Cadastre were found by Landsat images, we conclude that it is not correct to make a conclusion about long-term trends of aufeis area based on the entire dataset created. Following Pavelsky and Zarnetske (2017), we decided to examine only several of the largest aufeis fields in order to identify the long-term trend.

We selected the 38 largest aufeis fields with an area $\geq$ $10 \mathrm{~km}^{2}$ according to the Cadastre dataset, confirmed by satellite data. Their total area decreased from $858.1 \mathrm{~km}^{2}$ according to the Cadastre to $356.3 \mathrm{~km}^{2}$ according to recent Landsat images. Conversely, we also selected the largest aufeis fields according to satellite data (18 aufeis fields with satelliteestimated area $\geq 10 \mathrm{~km}^{2}$ ). Their total area also decreased significantly (from $428.6 \mathrm{~km}^{2}$ according to the Cadastre to $343.5 \mathrm{~km}^{2}$ according to Landsat images). We also analysed eight giant aufeis fields with areas $\geq 35 \mathrm{~km}^{2}$ according to the Cadastre dataset. They all were confirmed by the satellite images; however seven of the eight had a significantly smaller area (from 2 to $21 \mathrm{~km}^{2}$ ), with a decrease of 2-10 times. Only one giant aufeis field in the Syuryuktyakh River basin has the area detected by Landsat larger than that detected by Cadastre, at 72 and $64 \mathrm{~km}^{2}$ respectively. It should be noted that the formation of new (mainly small) aufeis fields can slightly reduce the rate of the aufeis area decrease.

\section{Data availability}

The combined digital database of the aufeis is publicly available and can be downloaded from https://doi.org/10.1594/PANGAEA.891036 (Makarieva et al., 2018b).

\section{Conclusions}

The research conducted here is the first step of the study aimed at the development of a GIS database of the aufeis of North-east Russia. Historical data of the Cadastre (1958) and topographic maps were used to create a geodatabase of aufeis in the Indigirka River basin (up to the Vorontsovo gauge, with the area of $305000 \mathrm{~km}^{2}$ ). It contains historical data on 896 aufeis fields with a total area of $2063.6 \mathrm{~km}^{2}$. Aufeis detection was conducted for the 2013-2017 period using Landsat imagery, with 1213 aufeis fields identified with a total area of $1287.4 \mathrm{~km}^{2}$. The historical dataset from the Cadastre (1958) and a more recent satellite-based dataset were compared and combined in the joint Catalogue of aufeis within the In- 
digirka River basin, available at the PANGAEA repository (https://doi.org/10.1594/PANGAEA.891036).

The recent total aufeis area is 1.6 times smaller than stated in the Cadastre (1958). More significant changes occurred in 38 large and giant aufeis fields (area $\geq 10 \mathrm{~km}^{2}$ ), with a total decrease of area by $501.8 \mathrm{~km}^{2}$ (or $66 \%$ of the total reduction). Simultaneously, the historical Cadastre archive is lacking data on over 600 aufeis fields that were identified using satellite images. This suggests that the Cadastre data are incomplete, while there may also have been significant change in aufeis formation conditions in the last half-century.

The analysis of large and giant aufeis seems to indicate that there has been a significant decrease in aufeis area over the period of the last 70 years. Additional analysis of historical aerial photography data could help to clarify the issue of the aufeis area decline trend from the middle of the 20th century to the present. One of the further study goals will be to find out the extent to which these changes are climate-derived and to identify their impact on river streamflow.

Author contributions. OM and NN designed the study. The historical aufeis dataset from Cadastre and topographic maps was compiled by AO. Identification of aufeis based on Landsat data and the cross-referencing between historical and satellite-based aufeis data collection were performed by AS. The initial draft of the paper was written by OM and NN, with contributions by AO (Sect. 3.2) and AS (Sects. 3 and 4). All authors contributed to the final form of the paper.

Competing interests. The authors declare that they have no conflict of interest.

Acknowledgements. The authors are grateful to David Post, Anna Liljedahl and an anonymous reviewer for valuable comments and assistance with English.

Edited by: Kirsten Elger

Reviewed by: Anna Liljedahl and one anonymous referee

\section{References}

Alekseev, V. R.: Naledi, Novosibirsk, Nauka, Moscow, 1987 (in Russian).

Alekseev, V. R.: Landscape indication of aufeis phenomena, Novosibirsk, Nauka, 364 p., 2005 (in Russian).

Alekseev, V. R.: Cryogenesis and geodynamics of icing valleys, Geodyn. Tectonophys., 6, 171-224, https://doi.org/10.5800/GT2015-6-2-0177, 2015.

Alekseev, V. R.: Long-term variability of the spring taryn-aufeis, Ice and Snow, 56, 73-92, https://doi.org/10.15356/2076-6734-20161-73-92, 2016.

Ananicheva, M. D.: Estimation of the areas, volumes and heights of the boundary of the feeding of glacier systems of the Northeast of Russia from the space images of the beginning of the $21 \mathrm{st}$ century, Ice and Snow, 1, 35-48, 2014.

Atlas of snow and ice resources of the world: 11 (2), Institute of geography RAS, Moscow, 270 pp., 1997 (in Russian).

Aufeis of Siberia and the Far East: Nauka, Novosibirsk, 244 pp., 1981 (in Russian).

Bense, V. F., Kooi, H., Ferguson, G., and Read, T.: Permafrost degradation as a control on hydrogeological regime shifts in a warming climate, J. Geophys. Res., 117, F03036, https://doi.org/10.1029/2011JF002143, 2012.

Bring, A., Fedorova, I., Dibike, Y., Hinzman, L., Mård, J., Mernild, S. H., Prowse, T., Semenova, O., Stuefer, S. L., and Woo, M.-K.: Arctic terrestrial hydrology: A synthesis of processes, regional effects, and research challenges, J. Geophys. Res.-Biogeosci., 121, 621-649, https://doi.org/10.1002/2015JG003131, 2016.

Cadastre to the map of the naleds of the North-East of the USSR: Scale 1:2000 000, Shilnikovskaya Z. G., Central complex thematic expedition of the North-Eastern Geological Survey, Magadan, 398 pp., 1958 (in Russian).

Catalogue of Aufeis in the Baikal-Amur Railroad Zone: 1, Aufeis in the Upper Part of the Chara River Basin, Gidrometeoizdat, Leningrad, 63 pp., 1980 (in Russian).

Catalogue of Aufeis in the Baikal-Amur Railroad Zone: 2, Aufeis in the Muya River Basin, Gidrometeoizdat, Leningrad, 84 pp., 1981 (in Russian).

Catalogue of Aufeis in the Baikal-Amur Railroad Zone: 3, Aufeis in the Upper Angara River Basin, Gidrometeoizdat, Leningrad, 96 pp., 1982 (in Russian).

Chavez Jr., P. S.: Image-based atmospheric corrections - Revisited and improved, Photogram. Eng. Remote Sens., 62, 1025-1036, 1996.

Danielson, J. J. and Gesch, D. B.: Global multi-resolution terrain elevation data 2010 (GMTED2010): U.S. Geological Survey Open-File Report 2011-1073, 26 pp., 2011.

Explanatory note to the geocryological map of the USSR, scale 1 : 2500000,125 pp., 1991 (in Russian).

Ge, S., McKenzie, J., Voss, C., and Wu, Q.: Exchange of groundwater and surface-water mediated by permafrost response to seasonal and long term air temperature variation, Geophys. Res. Lett., 38, L14402, https://doi.org/10.1029/2011GL047911, 2011.

GLIMS and NSIDC: Global Land Ice Measurements from Space glacier database. Compiled and made available by the international GLIMS community and the National Snow and Ice Data Center, Boulder CO, USA, https://doi.org/10.7265/N5V98602, 2005 (updated 2017).

Grosse, G. and Jones, B. M.: Spatial distribution of pingos in northern Asia, The Cryosphere, 5, 13-33, https://doi.org/10.5194/tc5-13-2011, 2011.

Hall, D. K., Riggs, G. A., and Salomonson, V. V.: Development of methods for mapping global snow cover using Moderate Resolution Imaging Spectroradiometer (MODIS) data, Remote Sens. Environ., 54, 127-140, 1995.

Kane, D. L. and Slaughter C. W.: Recharge of a central Alaska lake by subpermafrost groundwater, Natl. Acad. Sci. USA, 38, 458462, 1973.

Makarieva, O., Nesterova, N., Post, D. A., Sherstyukov, A., and Lebedeva, L.: Warming temperatures are impacting the hydrometeorological regime of Russian rivers in the zone of continuous 
permafrost, The Cryosphere Discuss., https://doi.org/10.5194/tc2018-157, in review, 2018a.

Makarieva, O., Shikhov, A., Ostashov, A., and Nesterova, N.: Aufeises (naleds) of the North-East of Russia: GIS catalogue for the Indigirka River basin (Russia), PANGAEA, Data set, https://doi.org/10.1594/PANGAEA.891036, 2018 b.

Markov, M. L., Vasilenko, N. G., and Gurevich, E. V.: Icing fields of the BAM zone: expeditionary investigations, $\mathrm{SPb}$.: NestorHistory, 320 pp., 2016 (in Russian).

Morse, P. D. and Wolfe, S. A.: Geological and meteorological controls on icing (aufeis) dynamics (1985 to 2014) in subarctic Canada, J. Geophys. Res.-Earth Surf., 120, 1670-1686, 2015.

Pavelsky, T. M. and Zarnetske, J. P.: Rapid decline in river icings detected in Arctic Alaska: Implications for a changing hydrologic cycle and river ecosystems, Geophys. Res. Lett., 44, 3228-3235, 2017.

Pollard, W. H.: Icing processes associated with high Arctic perennial springs, Axel Heiberg Island, Nunavut, Canada, Permafr. Perigl. Process., 16, 51-68, 2005.

Pomortsev, O. A., Kashkarov, E. P., and Popov, V. F.: Aufeis: global warming and processes of ice formation (rhythmic basis of longterm prognosis), Bull. Yakutsk State University, 7, 40-48, 2010 (in Russian).

Reedyk, S., Woo, M. K., and Prowse, T. D.: Contribution of icing ablation to streamflow in a discontinuous permafrost area, Can. J. Earth Sci., 32, 13-20, 1995.

Rennermalm, A. K., Wood, E. F., and Troy, T. J.: Observed changes in pan-arctic cold-season minimum monthly river discharge, Clim. Dynam., 35, 923-939, 2010.

Romanovsky, V. E., Sazonova, T. S., Balobaev, V. T., Shender, N. I., and Sergueev, D. O.: Past and recent changes in air and permafrost temperatures in eastern Siberia, Global Planet. Change, 56, 399-413, https://doi.org/10.1016/j.gloplacha.2006.07.022, 2007.

Simakov, A. S. and Shilnikovskaya, Z. G.: The map of the naleds of the North-East of the USSR. A Brief Explanatory Note, The North-Eastern Geological Survey of the Main Directorate of Geology and Subsoil Protection, Magadan, 40 pp., 1958a (in Russian).
Simakov, A. S. and Shilnikovskaya, Z. G.: Map of the naleds of the North-East of the USSR Scale 1:2000 000, The North-Eastern Geological Survey of the Main Directorate of Geology and Subsoil Protection, Central complex thematic expedition, Magadan, 1958 b (in Russian).

Slaughter, C. W.: Occurrence of and recurrence of aufeis in an upland taiga catchment, in: Brown Memorial Volume - Proceedings of the 4th Canadian Permafrost Conference, edited by: Roger J. E., Natl. Res. Counc. of Can., Ottawa, Ont, 182-188, 1982.

Sokolov, B. L.: Naleds and river runoff. Gidrometeoizdat, Leninrgad, 190 pp., 1975 (in Russian).

Surface waters resources of the USSR: 17, Leno-Indigirsky district. Gidrometeoizdat, Leningrad, 651 pp., 1972 (in Russian).

Tananaev, N. I., Makarieva, O. M., and Lebedeva, L. S.: Trends in annual and extreme flows in the Lena River basin, Northern Eurasia, Geophys. Res. Lett., 43, 10764-10772, https://doi.org/10.1002/2016GL070796, 2016.

Tolstikhin, O. N.: Naleds and ground waters in the North-East of the USSR, Science, Novosibirsk, 164 pp., 1974 (in Russian).

Topchiev, A. G.: Methods of aerospace monitoring of aufeis geosystems and underground water of cryolithozone, Systems and means of informatics, 18, 304-327, 2008 (in Russian)

US Geological Survey Server: available at: http://earthexplorer. usgs.gov, last access: 1 August 2018.

Walvoord, M. A. and Kurylyk, B. L.: Hydrologic Impacts of Thawing Permafrost - A Review, Vadose Zone J., 15, 20 pp., https://doi.org/10.2136/vzj2016.01.0010, 2016.

Walvoord, M. A., Voss, C. I., and Wellman, T. P.: Influence of permafrost distribution on groundwater flow in the context of climate-driven permafrost thaw: Example from Yukon Flats Basin, Alaska, United States, Water Resour. Res., 48, W07524, https://doi.org/10.1029/2011WR011595, 2012.

Yde, J. C. and Knudsen, N. T.: Observations of debris-rich naled associated with a major glacier surge event, Disko Island, west Greenland, Permafr. Perigl. Process., 16, 319-325, 2005.

Yoshikawa, K., Hinzman, L. D., and Kane, D. L.: Spring and aufeis (icing) hydrology in Brooks Range, Alaska, J. Geophys. Res.Biogeosci., 112, 1-14, 2007. 